Article

\title{
Flood Risk Mapping Worldwide: A Flexible Methodology and Toolbox
}

\author{
Hanne Glas ${ }^{1, *} \mathbb{0}$, Ivan Rocabado ${ }^{2}$, Steven Huysentruyt ${ }^{2}$, Edith Maroy ${ }^{2}$, \\ Danitza Salazar Cortez ${ }^{2}$, Kobe Coorevits ${ }^{2}$, Philippe De Maeyer ${ }^{3}$ and Greet Deruyter ${ }^{1,3}$ (D) \\ 1 Department of Civil Engineering, Ghent University, Valentin Vaerwyckweg 1, 9000 Ghent, Belgium; \\ greet.deruyter@ugent.be \\ 2 Antea Group Belgium, Buchtenstraat 9, 9051 Ghent, Belgium; ivan.rocabado@anteagroup.com (I.R.); \\ steven.huysentruyt@anteagroup.com (S.H.); edith.maroy@anteagroup.com (E.M.); \\ danitza.salazarcortez@anteagroup.com (D.S.C.); kobe.coorevits@anteagroup.com (K.C.) \\ 3 Department of Geography, Ghent University, Krijgslaan 281, 9000 Ghent, Belgium; \\ philippe.demaeyer@ugent.be \\ * Correspondence: hanne.glas@ugent.be
}

Received: 29 August 2019; Accepted: 7 November 2019; Published: 13 November 2019

\begin{abstract}
Flood risk assessments predict the potential consequences of flooding, leading to more effective risk management and strengthening resilience. However, adequate assessments rely on large quantities of high-quality input data. Developing regions lack reliable data or funds to acquire them. Therefore, this research has developed a flexible, low-cost methodology for mapping flood hazard, vulnerability and risk. A generic methodology was developed and customized for freely available data with global coverage, enabling risk assessment worldwide. The default workflow can be enriched with region-specific information when available. The practical application is assured by a modular toolbox developed on GDAL and PCRASTER. This toolbox was tested for the catchment of the river Moustiques, Haiti, for which several flood hazard maps were developed. Then, the toolbox was used to create social, economic and physical vulnerability maps. These were combined with the hazard maps to create the three corresponding flood risk maps. After creating these with the default data, more detailed information, gathered during field work, was added to verify the results of the basic workflow. These first tests of the developed toolbox show promising results. The toolbox allows policy makers in developing countries to perform reliable flood risk assessments and generate the necessary maps.
\end{abstract}

Keywords: flood hazard map; vulnerability; flood risk; open source; Haiti

\section{Introduction}

Globally, natural hazards result in a loss of 42 million lives annually, while the average economic loss amounts to USD 293 billion [1]. Flooding is not only the hazard with the highest impact on lives and livelihood [2], but it is also the most complex one to model and thus prepare for, due to the large amount of possible drivers, including extreme precipitation, dam breaks, tsunamis and storm surges [3]. Moreover, flood risk has shown a large increase in the past decades as a result of population growth, urbanization and poor land use practices in flood prone areas [4]. Climate change and socio-economic development will further modify the frequency, intensity and regularity of floods and other hazards, especially in already vulnerable regions [3].

As material and human losses caused by flood events continue to increase year by year, so does the importance of an adequate estimation of these losses. Flood risk assessments predict the potential consequences of flooding and indicate the high-risk areas [5]. The approach focuses on minimizing 
these consequences and the corresponding costs rather than minimizing the flood event itself. The importance of this shift in focus, was emphasized by the United Nations Secretary-General António Guterres on the International Day for Disaster Risk Reduction 2017, where he stated, "The challenge is to move from managing disasters themselves to managing disaster risk," [6]. Flood risk assessments lead to more effective risk management and strengthen the resilience of a community [3]. Therefore, several countries and regions have adapted this methodology into region-specific flood risk assessment tools. Examples of such tools are HAZUS M-H Flood model in the United States [7], HISS-SSM in the Netherlands [8], FLEMO in Germany [9] and LATIS in Flanders, Belgium [5]. These models, which are all designed for assessment in developed regions, are characterized by their dependence on large quantities of high-quality input data $[9,10]$. While over the past years, many researchers have worked on computing accurate local flood risk models, with promising results, data scarcity remains a hurdle for the development of global models as well as for flood risk assessment in developing countries, which lack the funds to acquire reliable and detailed input data [3].

In data-poor regions, mapping flood risk requires innovative and customized approaches. Remote sensing data is an important information source in many of these cases. In Cambodia, multi-temporal remote sensing data was used as only input for a flood assessment [11]. In another study, a rice crop damage map was created for a floodplain in Cambodia by combining remote sensing data with a Digital Elevation Model (DEM) and land use data of the region [12]. In the Kashmir Valley in India, the assessment of the flood risk was done solely based on satellite imagery [13]. For study areas in Haiti, flood maps were developed based on a single historic flood event or derived from intensity-duration-frequency (IDF) curves, as more historic data was inexistent $[14,15]$. Although these studies have valuable results for their respective study areas, the implementation of these methodologies on a wider scale is hindered by the individuality of the approaches.

Therefore, this research has developed a flexible, low-cost methodology for mapping flood hazard, vulnerability and risk in data-poor regions. As the risk mapping is based on freely available input data with global coverage, the methodology is applicable worldwide. A modular framework for the risk calculations was developed, which allows the default workflow to be extended and enriched with optional modules that make use of region-specific, detailed information when available. The practical application is designed as a modular toolbox developed on GDAL and PCRASTER. Hence, the framework and toolbox provide a generic set of algorithms and spatiotemporal calculations for mapping flood hazard, vulnerability and risk that can be enhanced to account for local specificities. A user-interface allows access to the toolbox and modification of the algorithms without any programming experience.

\section{Materials and Methods}

\subsection{Definitions}

The United Nations Office of Disaster Risk Reduction (UNDRR) defines risk as the combination of the probability of a hazardous event and its negative consequences which result from interactions between natural or man-made hazard(s), vulnerability, exposure and capacity [16]. Capacity is described as the combination of all the strengths, attributes and resources available within the system to manage and reduce disaster risks and strengthen resilience. While incorporating capacity can offer valuable and interesting insights, quantifying this correctly requires a large amount of location-specific input data. As this is contradictory with the research aim, the proposed method leaves aside capacity and follows the conventional notation of risk: Risk $=$ Hazard $\times$ Vulnerability. As such, three main modules were defined in the workflow: Hazard, vulnerability and risk.

Hazard is a broad term, that is described as a process, phenomenon or human activity that may cause loss of life, injury or other health impacts, property damage, social and economic disruption or environmental degradation [16]. In this research, the hazard module is limited to flooding as a single event. The probability of flooding in the study area is determined through statistical analysis [5]. The 
resulting flood hazard maps are calculated for specific return periods, expected periods of time in which a particular water level and discharge may occur, depicting the corresponding water extents and flood heights.

Vulnerability is defined by the UNDRR as a set of conditions and processes resulting from physical, social and economic factors, which increase the susceptibility of a community to the impact of the hazard [16]. This research takes into account three types of vulnerability caused by flooding: Social, physical and economic vulnerability. Social vulnerability is defined by the number of people vulnerable to a potential flood; physical vulnerability is determined by the potential material damages; and economic vulnerability comprises the potential economic damages.

In this research, risk is calculated by combining the vulnerability maps with the flood hazard data for different return periods. Social risk is defined as the potential number of casualties due to flooding each year. The risk level for material damages is described in physical risk, while economic risk determines the risk level for economic damages. Both are initially calculated in USD $/ \mathrm{m}^{2} /$ year and then classified in five risk levels.

\subsection{Methodology Workflow}

The total workflow is visualized in Figure 1 and can be divided in three large modules. The hazard and vulnerability modules run independently from one another, while the risk module depends on input data from the first two.

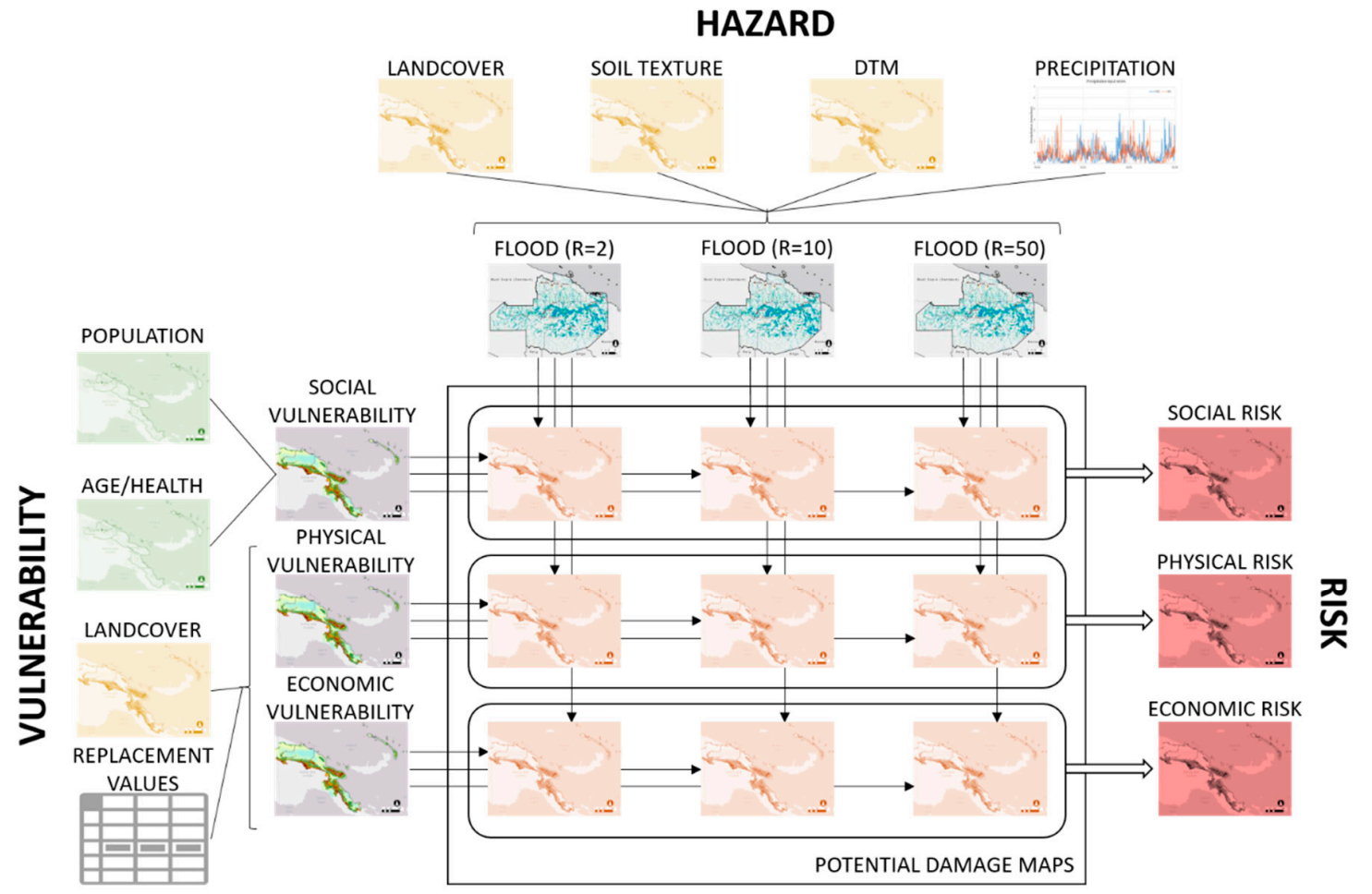

Figure 1. Workflow of flood risk mapping, as followed in the developed toolbox.

\subsubsection{Hazard Module}

Flood hazard is mapped in terms of flood heights and extent using the modelling framework proposed by Roo and Jetten at the Univerity of Twente: openLISEM [17,18]. openLISEM is a publicly available spatial hydrological model that can simulate runoff, sediment dynamics and shallow floods. Only the components modelling rainfall-runoff and hydrodynamic flows were used for calculating flood hazard. 
The spatially distributed rainfall runoff model generates runoff for a specific rainfall event based on the physical processes of interception, infiltration and surface storage. The size of each gridcell is first corrected for slope, assuming rain is vertical. Interception is calculated for different types of vegetation based on canopy openness and Leaf Area Index $[19,20]$. Then, the Micro Depression Storage (MDS) equation proposed by Kamphorst et al. is used to estimate the fraction of water that is stored in micro depressions at the surface and the fraction that contributes to runoff based on surface roughness (RR) [21]. This empirical equation was determined through the analysis of 221 digital elevation models of various types of micro relief. Infiltration is calculated for each cell with the infiltration method from Green \& Ampt, mostly sensitivity to initial soil moisture and hydraulic conductivity [22]. Within the soil, vertical and lateral flows are calculated with Darcy's law according to local pressure gradients determined at any moment using the Farrell \& Larson Soil Water Retention Curve [23].

The hydrodynamics of surface flow are modelled using the community and momentum conservation equations for shallow water equations. These equations are solved with the open source numerical procedure of FullSWOF2D based on the following principles: (i) Cell boundary fluxes are estimated using step-wise linear approximations, (ii) water heights for each cell are reconstructed based on total incoming and outgoing fluxes, and (iii) fluxes are determined based on the linear reconstruction of water heights, velocities and bed elevations from the cells that touch the cell boundary [24].

The water flow is divided in three domains: overland flow (according to the DEM), channel flow (following the river network), and flooding. In this case study, the 1D kinematic wave equation was used for overland flow and channel flow, together with Manning's equation for flow velocity. The one-dimensional kinematic wave equation is applied along a local drainage direction network which links all cells of the catchment together, according to the direction of one of the 8 adjacent cells in a rectangular grid. The channel, defined by with, depth and side angle, is assumed in the middle of the cell and overland flow is considered perpendicular to it. Channel overflow is converted instantly into flooding water, that can flow back into the channel when the capacity allows it. Overland flow that reaches a flooded cell is added to the flood heights and affects velocity. More detail about the equations, assumptions and numerical solutions used in openLISEM can be found in the documentation of the software [25].

The equations describing the processes described above are parameterized with spatially-distributed parameters associated with land cover, soil, relief and channel characteristics. The required maps are listed in Table 1. The workflow of pre-processing and modelling steps is represented in Figure 2.

The chosen grid resolution depends on the available computing capacity (all maps are loaded in memory while the software is running) and on expectations for reasonable calculation time. In data-poor contexts, reasonable assumptions make it possible to generate the many input parameter maps based on soil texture, land cover classes and the digital terrain model alone. This can be done with predefined lookup tables based on the literature and automatized with an algorithm in PCRaster [26]. Parameters were derived from GlobCover land cover classes $(300 \mathrm{~m} \times 300 \mathrm{~m})$ using a compilation of parameters based on various experimental studies as proposed by Liu \& De Smedt (2004) [21] for the 17 IGBP vegetation type classes [22]. For soil types, soil mapping units described in the FAO-UNESCO Soil Map of the World were first converted into likely USDA texture classes based on the fraction of fine, medium and coarse material. Hydrological parameters associated with USDA texture classes were then taken from Saxton et Rawls (2006) [23]. Elevation data is available globally at $30 \mathrm{~m}$ horizontal resolution (SRTM) but this is generally insufficient to describe accurately the morphology of the river network. Therefore, it is helpful to make use of more detailed information on hydrography, channel shape, depth and width, bed roughness, and location of outlets. Vector data of river networks is available in datasets such as HydroSHEDS or Openstreetmap or can be digitalized based on remote sensing and satellite images. River channels are rasterized and variables of length, width and depth are associated to each pixel. With limited knowledge about the geometry of the channel, width and 
depth are interpolated based on the distance to the outlet. Available information on roads and possible barriers can also be integrated into the model.

Table 1. Parameter maps used in the hydrological model openLISEM.

\begin{tabular}{|c|c|c|}
\hline Data & Derived Parameter Map & Symbol/Unit \\
\hline Rainfall series & Rainfall depth & $\left(\mathrm{mm} \mathrm{h}^{-1}\right)$ \\
\hline \multirow{4}{*}{ DEM } & Local Drain Direction (LLD) & \\
\hline & Outlet & \\
\hline & Gradient & $\mathrm{S}\left(\mathrm{mm}^{-1}\right)$ \\
\hline & Catchment delineation (optional) & \\
\hline \multirow{4}{*}{ Soil texture } & Hydraulic conductivity & Ksat $\left(\mathrm{mm} \mathrm{h}^{-1}\right)$ \\
\hline & Average suction at wetting front & $\Psi(\mathrm{cm})$ \\
\hline & Porosity & $\theta_{\mathrm{s}}$ \\
\hline & Initial moisture & $\theta_{\mathrm{i}}$ \\
\hline \multirow{5}{*}{ Land use/Land cover } & Surface random roughness & $\mathrm{RR}(\mathrm{cm})$ \\
\hline & Cover fraction & Cover (-) \\
\hline & Manning's roughness coefficient & $\mathrm{n}(-)$ \\
\hline & Leaf area index of the plant cover in a gridcell & $\operatorname{LAI}\left(\mathrm{m}^{2} / \mathrm{m}^{2}\right)$ \\
\hline & Crop height & $(\mathrm{m})$ \\
\hline \multirow{5}{*}{ Channel } & LDD channel & \\
\hline & Channel width & $(\mathrm{m})$ \\
\hline & Channel depth & $(\mathrm{m})$ \\
\hline & Side angle & $(-)$ \\
\hline & Gradient & $(-)$ \\
\hline
\end{tabular}

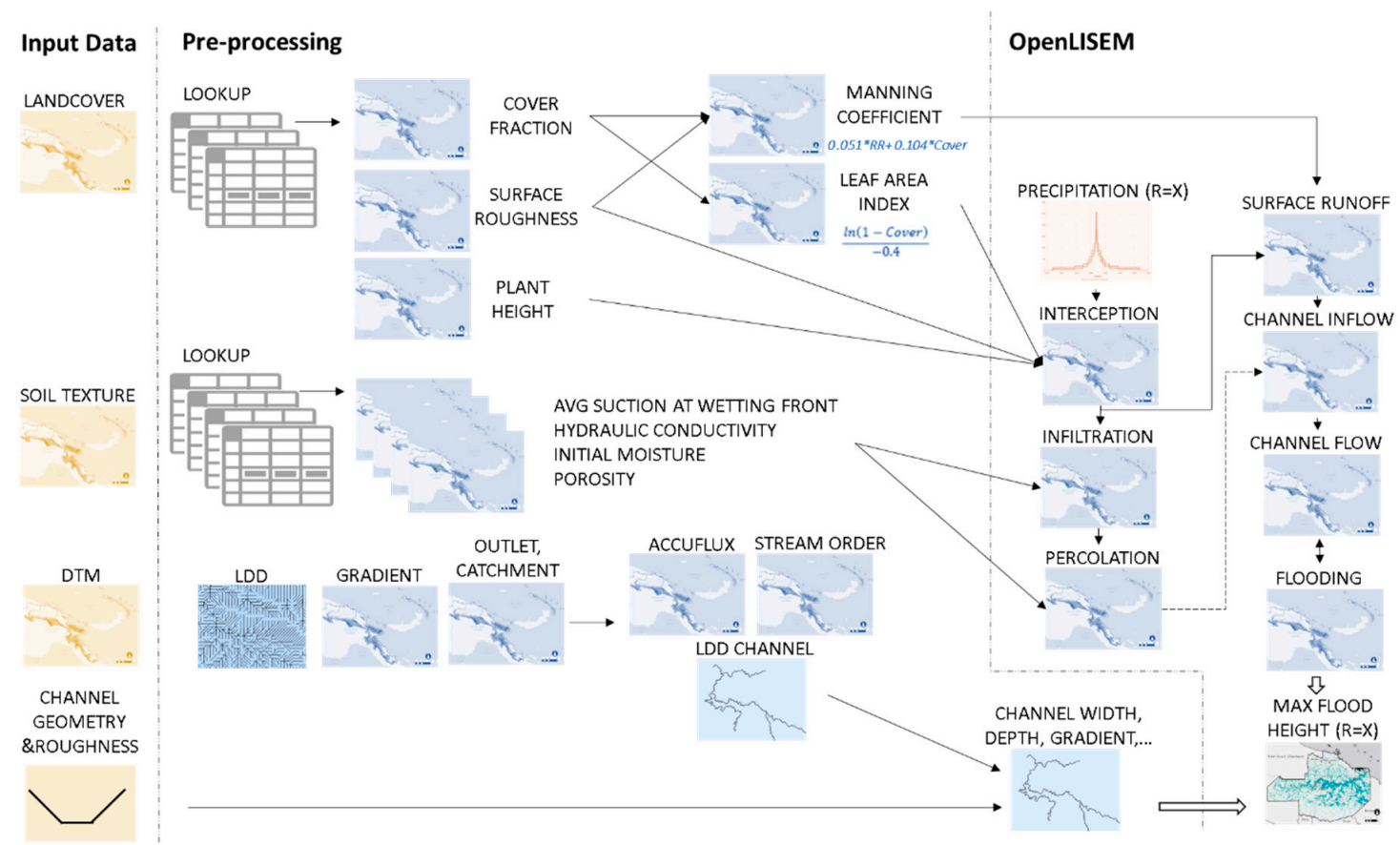

Figure 2. Workflow of the hazard module for floods as followed in the developed toolbox (preprocessing steps) and the OpenLISEM model. 
The notion of risk should combine a spectrum of different types of events, mild frequent ones as well as rare extreme ones. Therefore, hazard must be known for a number of return periods. This statistical component is derived from rainfall Intensity-Duration-Frequency curves. These curves are calculated by meteorological services across the world based on historical rainfall records and geostatistical methods. For each frequency of occurrence, or return period, all the most likely storms are plotted according to their duration and intensity. Typically, IDF curves illustrate that the shortest and least frequent storms have higher intensities. For the US and the Caribbean, IDF curves are made available online by the National Oceanic and Atmospheric Administration NOAA [24]. Alternatively, they can be computed based on rainfall intensity time series derived from microwave and radar data provided by satellites such as TRMM \& GPM (NASA) or the GSMaP project (JAXA). Adjustments and cross-validation with local measurements are however necessary to be able to take short rainfall events into account. Accuracy of short events will be of particular importance for small catchments (and higher regions within a catchment).

The openLISEM model simulates flow and flood areas based on a specific rainfall event however, rather than IDF curves. In order to associate a probability to each flood hazard map, composite storms are designed as to generate the highest possible runoff concentration for a certain probability of rain. The critical storm duration is well approximated by the concentration time, which is different for each point of a catchment. For upstream locations, short storm durations will be critical while, locations downstream, associated with larger catchments, will have longer critical storm durations. To make sure all critical floods are simulated everywhere on a catchment, all these various durations should be evaluated. As a simplification to such an expensive approach, "composite" design storms are proposed by Berlamont (1999) [27], who combines all critical storm durations into one single event. They are determined by setting out the rainfall volumes from the IDF-relationship symmetrically around the centre of the storm, starting from the shortest storm duration till the longest $\Delta t_{\max }$. The maximum duration $\Delta t_{\max }$ is chosen equal to the concentration time at the outlet.

The results of openLISEM and the proposed flood mapping strategy were verified against a similar analysis carried out for Papua New Guinea [26] which was validated using existing flood hazard maps for that region.

\subsubsection{Vulnerability Module}

Three types of vulnerability are mapped: social, physical and economic vulnerability. Figure 3 visualises the module default workflow, as well as the optional data that can be added.

In the default workflow, social vulnerability is defined by the population density, which is the only indispensable input data for this module. The default data in the workflow is the freely available WorldPop data. WorldPop distributes census population data based on land cover information, such as location of settlements, roads and rivers [27], resulting in maps with a $100 \mathrm{~m} \times 100 \mathrm{~m}$ resolution. However, when more detailed population distribution data is available this default data can be replaced with it. Furthermore, when age or health information is available, the workflow can be extended, adding a dependency ratio to the module. This factor is then multiplied with the number of people in an area to calculate the potential vulnerability of the area. The dependency ratio is defined as:

$$
D R=\frac{Y+S+L T S}{W}
$$

In this equation, DR stands for Dependency Ratio, $Y$ represents the number of children younger than $15, S$ the number of seniors older than 64, LTS the number of working people (aged 15-64) with a long-term sickness and $W$ the number of people at a working age (15-64). A large number of senior citizens, children and sick people will result into a factor higher than 1 that will be multiplied with the total number of inhabitants. On the other hand, a small amount of seniors, children and workers with a long-term sickness will result in a factor lower than 1 . In the final step, five vulnerability classes are defined, and the social vulnerability map is generated. 


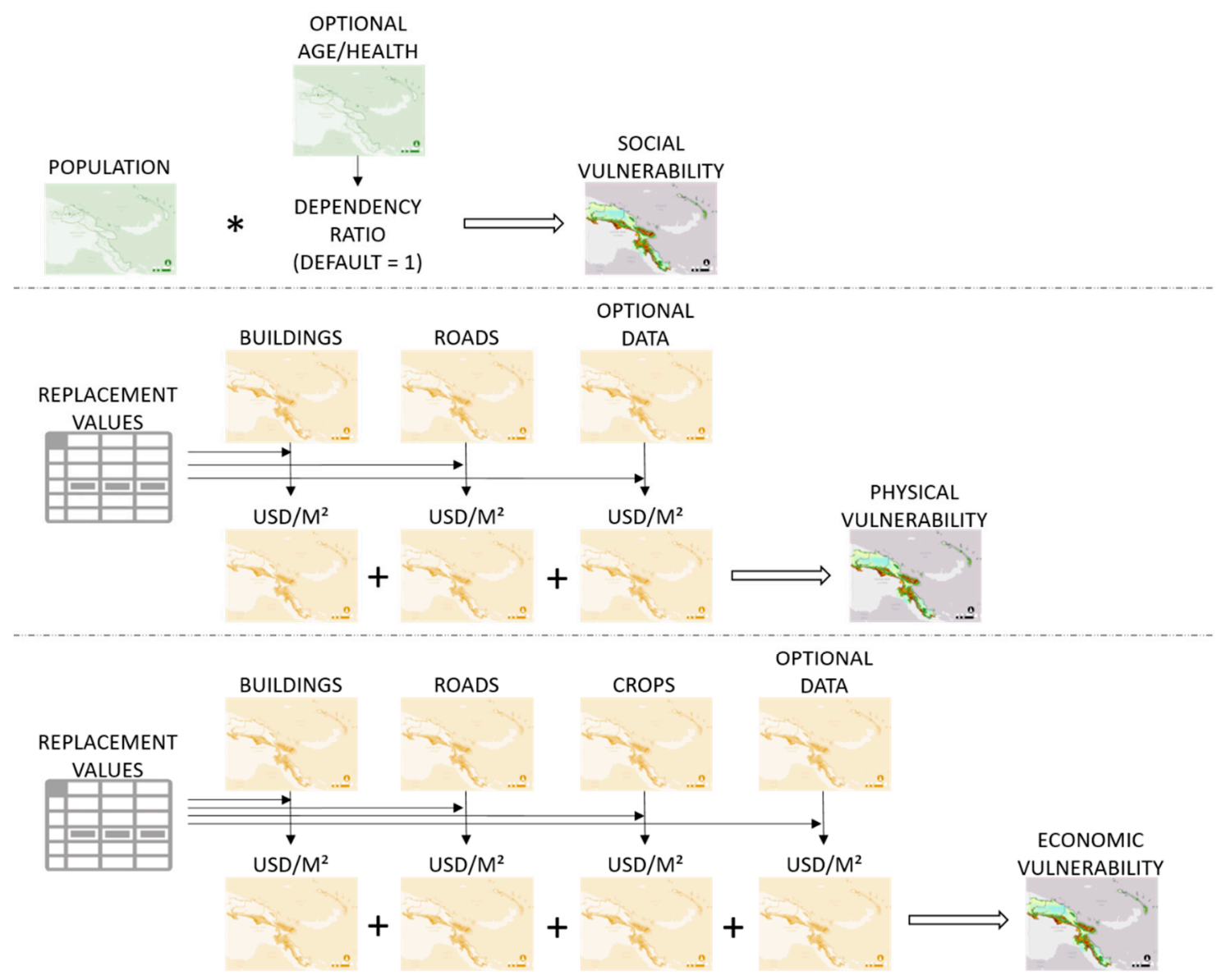

Figure 3. Workflow of the vulnerability module for social vulnerability (top), physical vulnerability (middle) and economic vulnerability (bottom), as followed in the developed toolbox.

Physical vulnerability only takes into account material damages to buildings and roads, while economic vulnerability also takes into account the economic damages to farmlands. Both physical and economic vulnerabilities are expressed in $\mathrm{USD} / \mathrm{m}^{2}$ and are based on freely available land cover data, combined with more detailed information on buildings, crops and roads. The default global land cover map used is GlobCover from ESA and has a spatial resolution of $300 \mathrm{~m} \times 300 \mathrm{~m}$ [28]. In a first step, this data is supplemented with detailed building and road data, available from OpenStreetMap. Combining these default datasets, creates the land cover map that is used as input for the economic and physical vulnerability calculations. However, it is also possible to add extra land cover data if available. In the next step, the land cover data are linked to a list with replacement values. These values represent the cost to rebuild an element at risk in case of complete destruction. The default replacement values were gathered from literature and reports. The crop costs were derived from data from the Food and Agricultural Organization of the United Nations (FAOSTAT) [29], Road cost was based on the unit cost data from the Roads Cost Knowledge System (ROCKS) developed by the World Bank's Transport Unit [28]. Both crop and road costs were calculated per country. Building replacement costs, on the other hand, were averaged per region in the world, based on reports from real estate consultancy businesses such as Turner \& Townsend and Compass International, Inc. [29,30]. It is also possible to add location-specific replacement values if available. Combining these values with the land cover map, and assigning each value to one of the five vulnerability classes, leads to the two vulnerability maps. 


\subsubsection{Risk Module}

The vulnerability and flood hazard maps generated in the previous modules form the main input data for the risk calculations. Figure 4 shows how the risk module combines both the resulting risk maps.

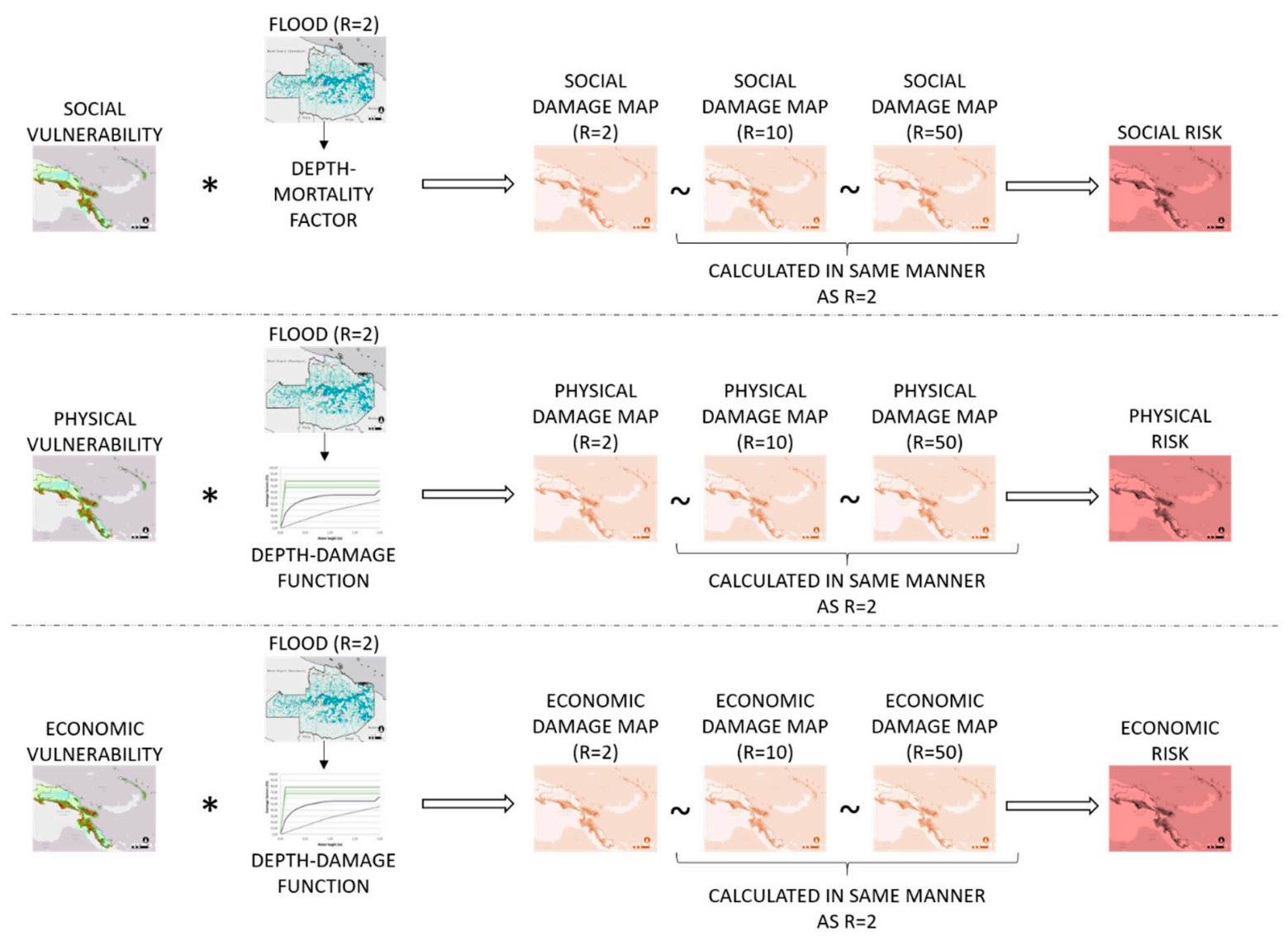

Figure 4. Workflow of the risk module for social risk (top), physical risk (middle) and economic risk (bottom), as followed in the developed toolbox.

The physical and economic vulnerability maps are combined with the flood hazard maps using depth-damage functions, which are gathered from literature and are added as default tables in the tool. Table 2 gives an overview of the default depth-damage functions available and their application scale and area. 
Table 2. Overview of default depth-damage functions available in the tool.

\begin{tabular}{|c|c|c|c|c|}
\hline $\begin{array}{l}\text { Depth-Damage } \\
\text { Function }\end{array}$ & Developed by & $\begin{array}{l}\text { Developing } \\
\text { Method }\end{array}$ & Application Scale & Application Area \\
\hline HAZUS Model & $\begin{array}{c}\text { Federal Insurance } \\
\text { Administration (FIA) \& US } \\
\text { Army Corps of Engineers } \\
\text { (USACE) }\end{array}$ & Expert judgment & $\begin{array}{l}\text { Local State } \\
\text { Regional }\end{array}$ & USA \\
\hline Rhine Atlas Model & $\begin{array}{c}\text { International Commission } \\
\text { for the Protection of the } \\
\text { Rhine (ICRP) }\end{array}$ & $\begin{array}{l}\text { Empirical } \\
\text { information }\end{array}$ & Catchment & $\begin{array}{c}\text { Rhine } \\
\text { Area/Germany }\end{array}$ \\
\hline LATIS & $\begin{array}{l}\text { Flemish Environment } \\
\text { Agency (FEA) }\end{array}$ & Expert judgment & Regional National & Flanders/Belgium \\
\hline $\begin{array}{c}\text { Damage scanner } \\
\text { Model }\end{array}$ & $\begin{array}{l}\text { Rijkswaterstaat Water, } \\
\text { Verkeer en Leefomgeving }\end{array}$ & Expert judgment & Regional National & The Netherlands \\
\hline $\begin{array}{l}\text { Joint Research } \\
\text { Centre Model }\end{array}$ & $\begin{array}{l}\text { Directorate General Joint } \\
\text { Research Centre (DG JRC) }\end{array}$ & $\begin{array}{l}\text { Average of all } \\
\text { assessed damage } \\
\text { functions }\end{array}$ & Continent & Worldwide \\
\hline $\begin{array}{l}\text { Multi-Colored } \\
\text { Manal Model }\end{array}$ & $\begin{array}{l}\text { Flood Hazard Research } \\
\text { Centre (FHRC) Middlesex } \\
\text { University }\end{array}$ & Expert judgment & Local Regional & UK \\
\hline FLEMO & $\begin{array}{l}\text { German Research Centre } \\
\text { for Geosciences }\end{array}$ & $\begin{array}{l}\text { Empirical } \\
\text { information }\end{array}$ & $\begin{array}{l}\text { Local Regional } \\
\text { National }\end{array}$ & Germany \\
\hline Japan & Dutta et al. [31] & Expert judgment & $\begin{array}{l}\text { Local Regional } \\
\text { National }\end{array}$ & $\begin{array}{l}\text { Japan/tropical } \\
\text { island states }\end{array}$ \\
\hline
\end{tabular}

Dependent on the location, scale and land cover of the study area, a different depth-damage function can be chosen. It is also possible to add another, more specific, function for a specific case study. The result is a series of potential damage maps, each corresponding to a potential flood event with a specific return period. These maps are combined using the formula [32]:

$$
R=\sum_{i=1}^{n} \frac{1}{i}\left(D_{i}-D_{i-1}\right)
$$

In this expression, $R$ is the risk, $D_{i}$ is the damage corresponding to the return period $i$ and $n$ is the highest return period. With this formula, risk is expressed as a composed summation of the damages of a flood that statistically occurs once a year and the extra damage of floods with higher return periods, that does not happen when a flood with a lower chance of occurring is passing by. Depending on the number of flood hazard maps, this formula can be adapted by interpolating between the available return periods. The result is a physical and economic risk map showing the risk in USD $/ \mathrm{m}^{2} /$ year. In a final step, these risk damages are classified into five categories, resulting in a qualitative risk map.

To calculate the social risk, a depth-mortality function is used that defines the relation between hazard and vulnerability. As there is only flood height information available in the flood hazard maps, the number of casualties is expressed with following depth-mortality function [33]:

$$
N=\exp (1.16 d-7.3) \times P
$$

In this expression, $N$ is the number of casualties, $d$ is the water height and $P$ is the potential vulnerable population per pixel, as calculated in the vulnerability module. The number of casualties becomes a proxy for potential social damage; the resulting damage maps are combined in an identical manner as physical and economic risk, using Formula (2). The final result is a social risk map that visualizes the number of casualties, divided in five risk classes. 


\subsection{Toolbox}

The flood risk mapping toolbox is a set of modules written in Python 3.6 relying on PCRaster 4.2 [26], GDAL, GeoPandas, Rasterio and Shapely as main libraries (Figure 5). In order to improve processing performance while using high resolution and/or wide extend maps, the toolbox takes advantage of the parallel computing module from PCRaster.

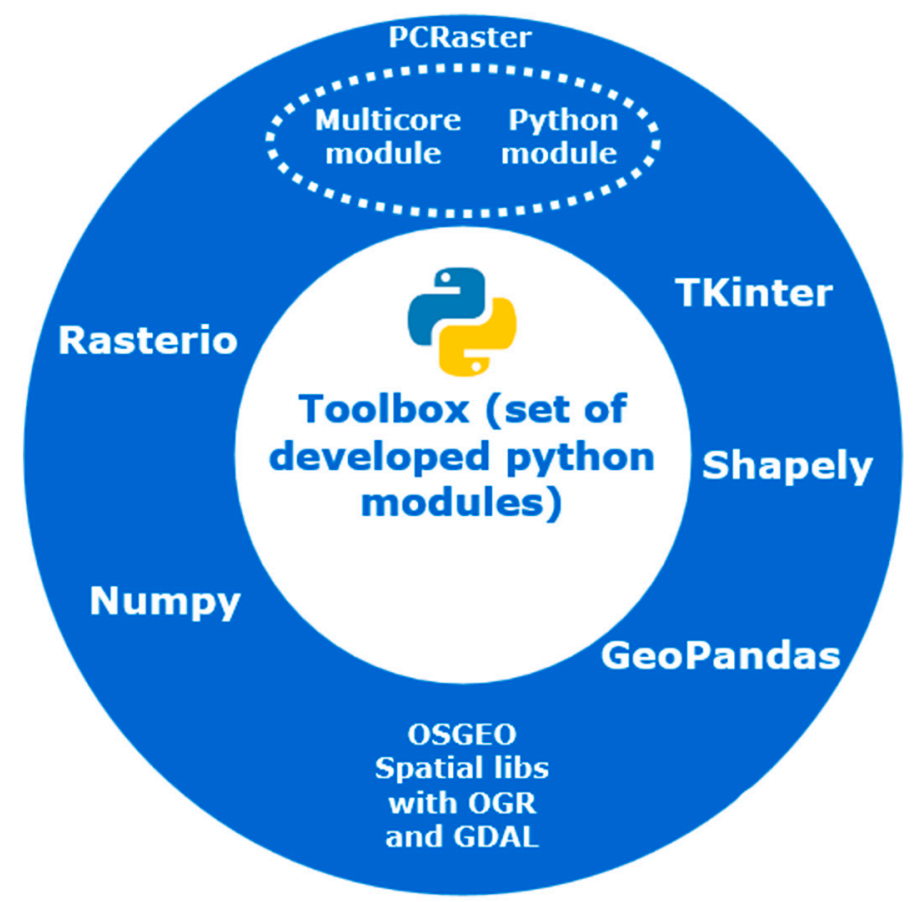

Figure 5. Flood risk mapping toolbox software schema.

The toolbox user interface (UI) is a set of input files in csv format describing the project meta data, information data folders, look up tables and files. The advanced syntax of these input files allows describing the workflow commands and complex functional relationships in a flexible manner.

The toolbox contains a built-in 'default' workflow, which consists of basic modules to create flood hazard, vulnerability and risk maps using open source and globally available data. Several depth-damage functions, each applicable for a specific geographic region, are available in the toolbox, Furthermore, the toolbox contains default replacement values that the user can apply when no location-specific socio-economic data is available.

While this default input is provided for users with a limited mapping knowledge, as listed in Table 3, the tool allows a mapping expert to customize the input files and workflow commands to better match each particular study case and particular methodology. The tool also enables splitting the main workflow to process separately either vulnerability or risk maps. Furthermore, the input can be customized to different locations and scales without any modification in the source code. 
Table 3. Overview of the input data for the three modules.

\begin{tabular}{|c|c|c|}
\hline Data Type & Mandatory & Source Used for Default Methodology \\
\hline \multicolumn{3}{|c|}{ HAZARD MODULE } \\
\hline Digital Terrain Model (DTM) & $\mathrm{Y}$ & SRTM DEM $(30 \times 30$ m resolution $)$ \\
\hline Landcover data & $\mathrm{Y}$ & Globcover $(300 \times 300 \mathrm{~m}$ resolution $)$ \\
\hline Soil texture data & $\mathrm{Y}$ & FAO-UNESCO Digital Soil Map of the World (vector) \\
\hline Precipitation data & $\mathrm{Y}$ & $\begin{array}{l}\text { IDF curves (national weather agencies, NOAA) or } \\
\text { rainfall intensity time series derived from TRMM \& } \\
\text { GPM (NASA) or GSMaP (JAXA). }\end{array}$ \\
\hline Channels/river network & $\mathrm{N}$ & OpenStreetMap (vector) \\
\hline \multicolumn{3}{|c|}{ VULNERABILITY MODULE } \\
\hline Population density data & Y & WorldPop $(100 \times 100$ m resolution $)$ \\
\hline \multirow{2}{*}{ Landcover data } & $\mathrm{Y}$ & Globcover $(300 \times 300 \mathrm{~m}$ resolution $)$ \\
\hline & Y & OpenStreetMap (vector) \\
\hline \multirow{3}{*}{ Replacement values } & Y & Crops-FAOSTAT [34] \\
\hline & Y & $\begin{array}{l}\text { Buildings-Turner \& Townsend [29] and Compass } \\
\text { International Inc. [30] }\end{array}$ \\
\hline & $\mathrm{Y}$ & Roads-ROCKS [28] \\
\hline \multicolumn{3}{|c|}{ RISK MODULE } \\
\hline Flood hazard maps & Y & Created in hazard module \\
\hline Vulnerability maps & Y & Created in vulnerability module \\
\hline Depth-damage functions & $\mathrm{Y}$ & see Table 2 \\
\hline Depth-mortality function & Y & Vrisou van Eck et al. [33] \\
\hline
\end{tabular}

\subsection{Study Area}

The developed toolbox was tested for the catchment of the river Moustiques, situated in the northwest of the island state Haiti. The catchment has 40,000 inhabitants and a total area of $222 \mathrm{~km}^{2}$ [35]. The $46 \mathrm{~km}$ long river is one of the only almost permanent waterways in this region characterized by an overall extremely dry climate. It rises from the mountain range Massif de Terre Neuve at a height of $697 \mathrm{~m}$ and flows into the Baie de Moustiques, a bay at the sea canal Canal de la Tortue between the mainland and the island Île de la Tortue. The hurricane season that runs from August through October is characterized by torrential rains and flash floods, leading up to $1200 \mathrm{~mm}$ measured precipitation per year [36]. Moreover, the Haitian government classified the plain of the Moustiques as vulnerable to exceptional hazards, such as cyclones, storms and hurricanes that produce as much as $600 \mathrm{~mm}$ precipitation in $24 \mathrm{~h}$ [37].

The study area lacks a hydro-meteorological gauging network; therefore, no reliable information regarding gauged rainfall nor flood discharges could be identified. Historical flood events were not documented and they remain only in the mind of the residents.

\section{Results}

In a first step, hazard, vulnerability and risk maps were derived following the basic algorithm: using the default, freely available input data only. In a subsequent step, more detailed information on the study area, gathered during a field mission, was introduced to improve the input data. This step enabled testing some of the optional modules, by providing extra in-depth information, but also testing alternative algorithms in the toolbox. Moreover, the results of the basic workflow were verified with this new set of more detailed vulnerability and risk maps. 


\subsection{Results Default Modules}

Using the hazard workflow, three flood hazard maps were created. The first has a return period of 2 years, the second one of 10 years and the last one has a 50-year return period. The default input data was complemented with an Intensity Duration Frequency (IDF) curve of West Puerto Rico (NOAA), as there was no IDF curve available for Haiti. However, the curve was compared to Cuban and Bahamian studies and was proven to be consistent for the Caribbean area. Three composite storms, presented in Figure 6, were designed based on the IDF curve to produce the flood hazard maps, shown in Figure 7.

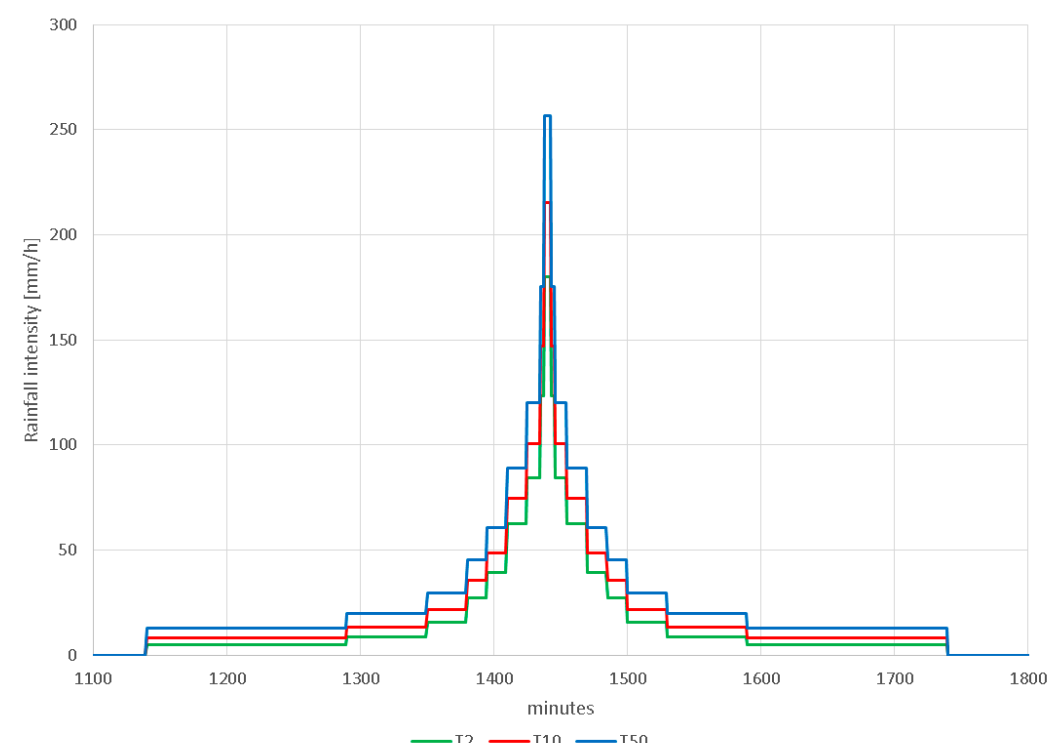

Figure 6. Composite storms for return periods 2, 10 and 50 years according to IDF-relationships in West Puerto Rico (NOAA).
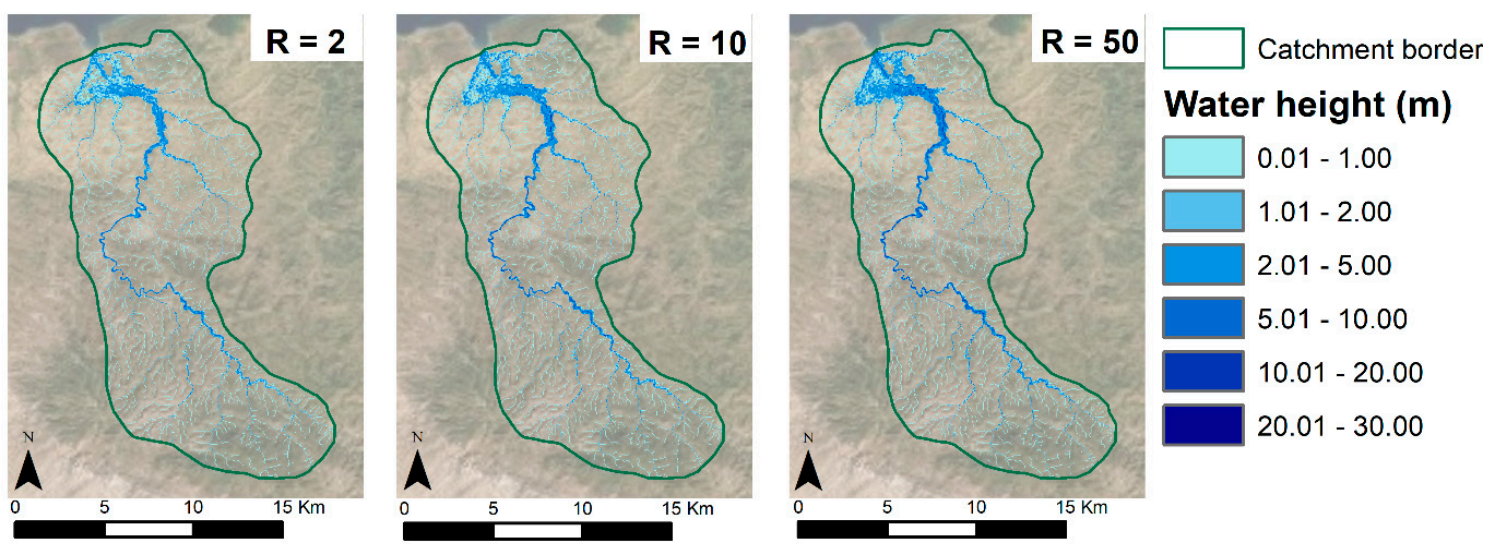

Figure 7. Flood hazard maps for three return periods of the catchment of the river Moustiques, Haiti, as created by the toolbox.

Due to the scale of the maps, they seem to show little to no difference. Therefore, a numerical comparison was made and depicted in Table 4 . Here, it becomes clear that the 50 -year return period has 2.16 percent more affected area than the 2-year return period and 1.07 percent more flooded area than the 10-year return period. Furthermore, especially the higher flood levels (more than $5 \mathrm{~m}$ ) occur more often during a 50-year-flood. The limited vertical accuracy of SRTM is at the basis of the apparent poor sensitivity. 
Table 4. Flooded area and numerical comparison for the three return periods in the catchment of the river Moustiques, Haiti.

\begin{tabular}{ccccccc}
\hline \multirow{2}{*}{$\begin{array}{c}\text { FLOOD } \\
\text { HEIGHT }\end{array}$} & \multicolumn{2}{c}{$\boldsymbol{R}=\mathbf{2}$ YEARS } & \multicolumn{2}{c}{$\boldsymbol{R}=\mathbf{1 0}$ YEARS } & \multicolumn{2}{c}{$\boldsymbol{R}=\mathbf{5 0}$ YEARS } \\
\cline { 2 - 6 } $\mathbf{( m )}$ & $\begin{array}{c}\text { Affected } \\
\left.\text { Area } \mathbf{( m}^{\mathbf{2}}\right)\end{array}$ & $\begin{array}{c}\text { \% of Total } \\
\text { Area }\end{array}$ & $\begin{array}{c}\text { Affected } \\
\text { Area }\left(\mathbf{m}^{\mathbf{2}}\right)\end{array}$ & $\begin{array}{c}\text { \% of Total } \\
\text { Area }\end{array}$ & $\begin{array}{c}\text { Affected } \\
\text { Area }\left(\mathbf{m}^{\mathbf{2}} \mathbf{)}\right.\end{array}$ & $\begin{array}{c}\text { \% of Total } \\
\text { Area }\end{array}$ \\
\hline $0.01-1.00$ & $16,324,500$ & 7.38 & $16,796,500$ & 7.59 & $17,346,000$ & 7.84 \\
$1.01-2.00$ & $4,797,500$ & 2.17 & $4,887,000$ & 2.21 & $4,694,000$ & 2.12 \\
$2.01-5.00$ & $6,347,000$ & 2.87 & $7,397,500$ & 3.34 & $8,114,000$ & 3.67 \\
$5.01-10.00$ & $1,364,000$ & 0.62 & $1,928,500$ & 0.87 & $2,974,000$ & 1.34 \\
$10.01-20.00$ & 111,000 & 0.05 & 346,500 & 0.16 & 590,000 & 0.27 \\
$20.01-30.00$ & 0 & 0.00 & 12,000 & 0.00 & 15,500 & 0.00 \\
TOTAL & $28,944,000$ & 13.08 & $31,368,000$ & 14.17 & $33,733,500$ & 15.24 \\
\hline
\end{tabular}

In the vulnerability module, three maps were created representing the social, economic and physical vulnerability of the catchment. Figure 8 shows these maps with the vulnerability classified in five vulnerability levels. Table 5 lists the exact vulnerability values linked to each level. These class values were chosen in order to create a clear visual result that highlights the high-risk areas in the catchment. The exact class values are based on the average population density and replacement values of the elements taken into account in the study area. Specific numerical information on the vulnerabilities is listed in Table 6. As the data from WorldPop aggregates the population data over the country surface, the population density is never zero. Therefore, the entire catchment appears vulnerable to social risk. The economic vulnerability is widespread as well, as more than 56 percent of the area is economically vulnerable. However, most of this vulnerable area only has a very low vulnerability level. These are mostly farmlands. The physical vulnerability looks much more limited in extend, as it takes into account land cover elements, namely buildings and roads which require a stronger zoom in the map to actually appreciate them in full.
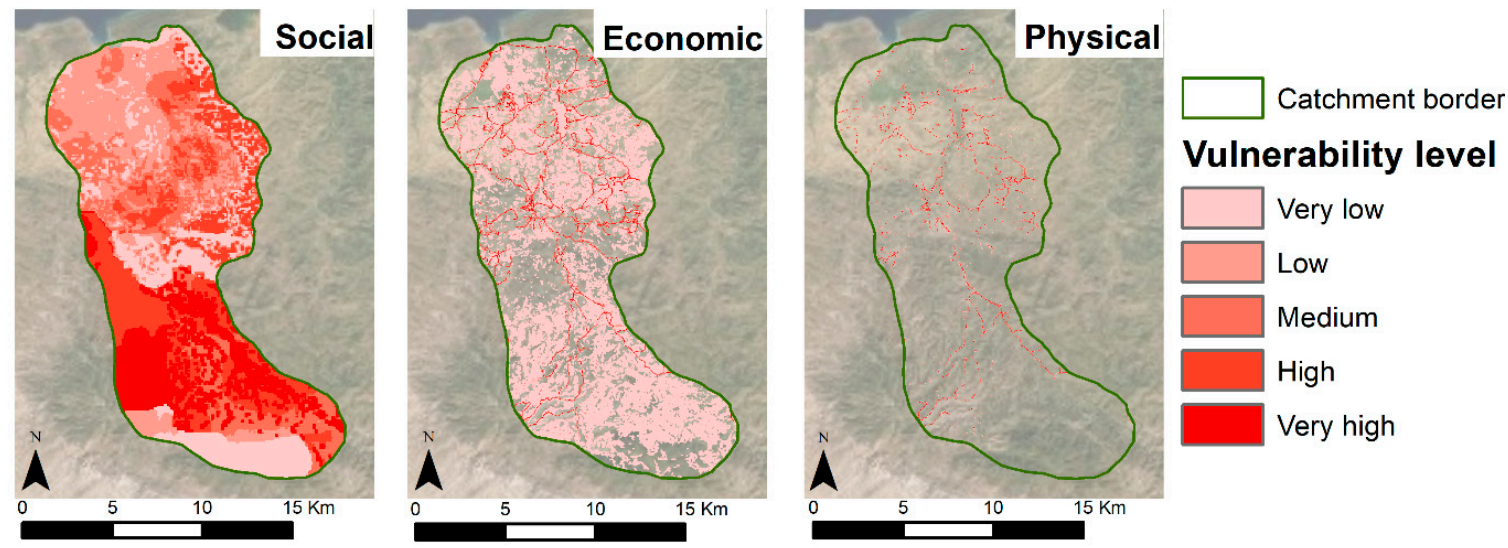

Figure 8. Social, Economic and physical vulnerability map of the catchment of the river Moustiques, Haiti, as created by the toolbox.

Table 5. Minimum and maximum values of vulnerability levels for social, economic and physical vulnerability in the catchment of the river Moustiques, Haiti.

\begin{tabular}{ccccccc}
\hline \multirow{2}{*}{$\begin{array}{c}\text { Vulnerability } \\
\text { Level }\end{array}$} & \multicolumn{2}{c}{ Social (People/ha) } & \multicolumn{2}{c}{ Economic $\left(\mathrm{USD} / \mathbf{m}^{\mathbf{2}}\right)$} & \multicolumn{2}{c}{ Physical $\left(\mathrm{USD} / \mathbf{m}^{\mathbf{2}}\right)$} \\
\cline { 2 - 6 } & Min Value & Max Value & Min Value & Max Value & Min Value & Max Value \\
\hline Very low & 0.01 & 0.50 & 0.01 & 0.50 & 0.01 & 0.50 \\
Low & 0.51 & 1.00 & 0.51 & 2.00 & 0.51 & 2.00 \\
Medium & 1.01 & 1.50 & 2.01 & 3.50 & 2.01 & 3.50 \\
High & 1.51 & 2.00 & 3.51 & 5.00 & 3.51 & 5.00 \\
Very high & 2.01 & $>2.01$ & 5.01 & $>5.01$ & 5.01 & $>5.01$ \\
\hline
\end{tabular}


Table 6. Vulnerable area and numerical information on social, economic and physical vulnerability in the catchment of the river Moustiques, Haiti.

\begin{tabular}{ccccccc}
\hline \multirow{2}{*}{$\begin{array}{c}\text { Vulnerability } \\
\text { Level }\end{array}$} & \multicolumn{2}{c}{ Social } & \multicolumn{2}{c}{ Economic } & \multicolumn{2}{c}{ Physical } \\
\cline { 2 - 7 } & $\begin{array}{c}\text { Vulnerable } \\
\left.\text { Area } \mathbf{( m}^{\mathbf{2}}\right)\end{array}$ & $\begin{array}{c}\text { \% of Total } \\
\text { Area }\end{array}$ & $\begin{array}{c}\text { Vulnerable } \\
\text { Area }\left(\mathbf{m}^{\mathbf{2}}\right)\end{array}$ & $\begin{array}{c}\text { \% of Total } \\
\text { Area }\end{array}$ & $\begin{array}{c}\text { Vulnerable } \\
\text { Area }\left(\mathbf{m}^{\mathbf{2}}\right)\end{array}$ & $\begin{array}{c}\text { \% of Total } \\
\text { Area }\end{array}$ \\
\hline Very low & $36,482,500$ & 16.48 & $109,837,000$ & 49.63 & $1,878,000$ & 0.85 \\
Low & $51,328,500$ & 23.19 & $3,938,500$ & 1.78 & $1,452,000$ & 0.66 \\
Medium & $44,797,500$ & 20.24 & $3,431,500$ & 1.55 & $1,490,000$ & 0.67 \\
High & $47,055,500$ & 21.26 & $2,228,000$ & 1.01 & $1,419,500$ & 0.64 \\
Very high & $41,652,500$ & 18.82 & $4,954,500$ & 2.24 & $1,439,000$ & 0.65 \\
TOTAL & $221,316,500$ & 100.00 & $124,389,500$ & 56.20 & $7,678,500$ & 3.47 \\
\hline
\end{tabular}

The last module combines the created flood and vulnerability maps into three risk maps depicting the yearly social, economic and physical risk. These maps are presented in Figure 9, while the case-study-specific risk level values are presented in Table 7 . The numerical information is summarized in Table 8. The social risk map clearly shows a higher risk upstream the river. This is due to the higher population density, and thus the higher social vulnerability in that area. 15.88 percent of the population, which is disseminated within 13.13 percent of the catchment area, is yearly at risk due to flooding. Economically, the elements in 14.22 percent of the catchment area are at risk, which is more than 25 percent of all vulnerable elements. The physical risk is limited to 0.81 percent of the total catchment area, but this is still more than 23 percent of the total physical vulnerable elements.
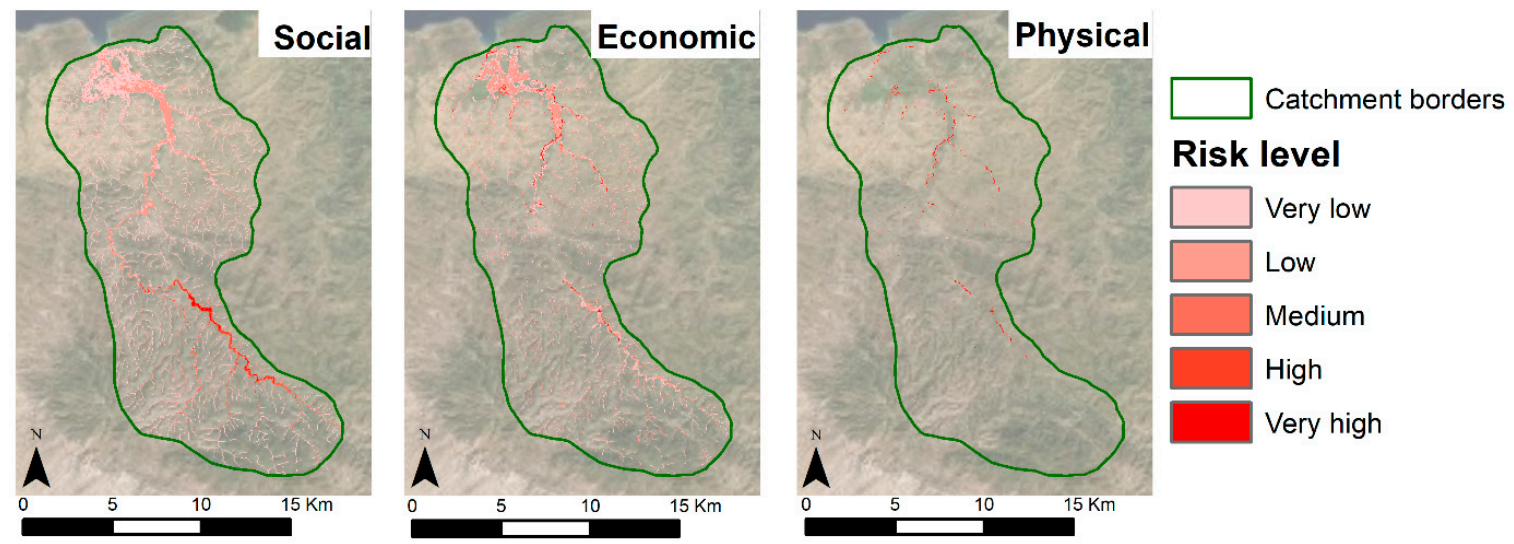

Figure 9. Social, Economic and physical risk map of the catchment of the river Moustiques, Haiti, as created by the toolbox.

Table 7. Minimum and maximum values of risk levels for social, economic and physical risk in the catchment of the river Moustiques, Haiti.

\begin{tabular}{ccccccc}
\hline \multirow{2}{*}{ Risk Level } & \multicolumn{2}{c}{ Social (People/ha) } & \multicolumn{2}{c}{ Economic $\left(\mathrm{USD} / \mathbf{m}^{\mathbf{2}}\right)$} & \multicolumn{2}{c}{ Physical $\left(\mathrm{USD} / \mathbf{m}^{\mathbf{2}}\right)$} \\
\cline { 2 - 6 } & Min Value & Max Value & Min Value & Max Value & Min Value & Max Value \\
\hline Very low & 0.01 & 0.25 & 0.01 & 0.10 & 0.01 & 0.10 \\
Low & 0.26 & 1.00 & 0.11 & 0.20 & 0.11 & 0.20 \\
Medium & 1.01 & 2.50 & 0.21 & 0.50 & 0.21 & 0.50 \\
High & 2.51 & 5.00 & 0.51 & 1.00 & 0.51 & 1.00 \\
Very high & 5.01 & $>5.01$ & 1.01 & $>1.01$ & 1.01 & $>1.01$ \\
\hline
\end{tabular}


Table 8. Area at risk area and numerical information on social, economic and physical risk in the catchment of the river Moustiques, Haiti.

\begin{tabular}{ccccccc}
\hline & \multicolumn{2}{c}{ Social } & \multicolumn{2}{c}{ Economic } & \multicolumn{2}{c}{ Physical } \\
\cline { 2 - 7 } Risk Level & $\begin{array}{c}\text { Area at Risk } \\
\mathbf{( m}^{\mathbf{2}} \mathbf{)}\end{array}$ & $\begin{array}{c}\text { \% of Total } \\
\text { Area }\end{array}$ & $\begin{array}{c}\text { Area at Risk } \\
\mathbf{( m}^{\mathbf{2}} \mathbf{)}\end{array}$ & $\begin{array}{c}\text { \% of Total } \\
\text { Area }\end{array}$ & $\begin{array}{c}\text { Area at Risk } \\
\left(\mathbf{m}^{\mathbf{2}} \mathbf{)}\right.\end{array}$ & $\begin{array}{c}\text { \% of Total } \\
\text { Area }\end{array}$ \\
\hline Very low & $19,541,500$ & 8.83 & $21,199,500$ & 9.58 & 333,000 & 0.15 \\
Low & $7,136,000$ & 3.22 & $9,033,000$ & 4.08 & 345,500 & 0.16 \\
Medium & $1,055,500$ & 0.48 & 437,000 & 0.20 & 371,500 & 0.17 \\
High & 972,500 & 0.44 & 424,000 & 0.19 & 354,000 & 0.16 \\
Very high & 348,000 & 0.16 & 388,000 & 0.18 & 398,500 & 0.18 \\
TOTAL & $29,053,500$ & 13.13 & $31,481,500$ & 14.22 & $1,802,500$ & 0.81 \\
\hline
\end{tabular}

\subsection{Comparison with Results Obtained with Optional Data}

In order to verify the results of the toolbox, the default risk maps were compared to the results of the workflow using more detailed input data. In order to calculate the social risk, detailed population information, on building level, was acquired. This data was gathered during fieldwork in 2018 [38]. The results of both scenarios are shown in Figure 10. While only $172,000 \mathrm{~m}^{2}$, or 0.42 percent of the total plain area, is classified as at risk using the detailed population data, the default workflow classifies $11,056,000 \mathrm{~m}^{2}$ or 27.22 percent of the total area as at risk.
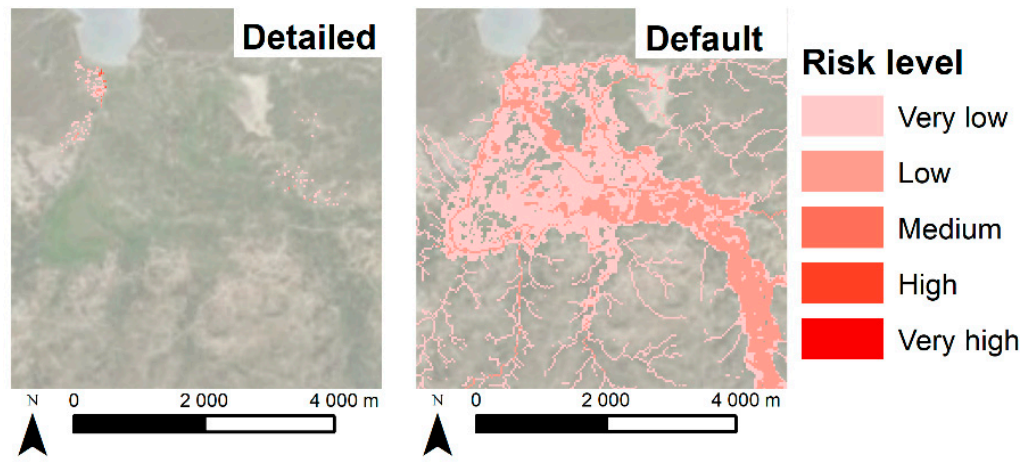

Figure 10. Comparison of the social risk map that was created using detailed input data and the optional modules (left) and the social risk map created using the default modules of the toolbox (right) for the plain of the catchment of the river Moustiques, Haiti.

Even more interesting is comparing the number of people vulnerable and at yearly risk in the two scenarios. 1846 people live in the plain according to the detailed population data. The WoldPop data, on the other hand, estimates the total number of inhabitants at 3143, an overestimation of more than 70 percent. When comparing the number of people at risk, however, the default data classifies barely half of the people as calculated with the detailed data as at risk, as 939 people are at risk according to the default method, while 1798 inhabitants are at risk using the detailed data.

The economic risk was calculated for the default data as well as for optional modules, including more detailed data on the farmlands, the crop types that are cultivated and the corresponding replacement values. This detailed information was only available for the plain of the catchment, so this was the only area taken into account in this comparison. Both resulting risk maps are shown in Figure 11. 

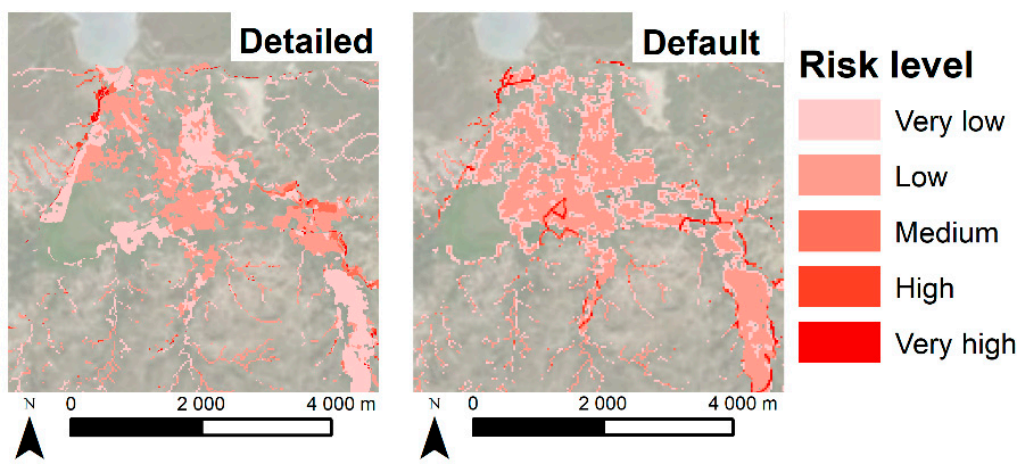

Figure 11. Comparison of the economic risk map that was created using detailed input data and the optional modules (left) and the economic risk map created using the default modules of the toolbox (right) for the plain of the catchment of the river Moustiques, Haiti.

Visually, it is clear that the risk computed with the default data is overestimated compared to the risk computed with more detailed data in the center of the plain. This is confirmed by the numerical analysis in Table 9. The default workflow calculates 12.6 percent more risk in the plain than the detailed information. The overestimation is mainly located in the low risk level.

Table 9. Area at risk and numerical information on the economic risk calculated by the optional modules using detailed input and the toolbox using the default modules and default input data for the plain of the catchment of the river Moustiques, Haiti.

\begin{tabular}{ccccc}
\hline \multirow{2}{*}{ Risk Level $(\mathbf{m})$} & \multicolumn{2}{c}{ Detailed } & \multicolumn{2}{c}{ Default } \\
\cline { 2 - 5 } & Area at Risk $\left.\mathbf{( m}^{\mathbf{2}}\right)$ & \% of Total Area & Area at Risk $\left.\mathbf{( m}^{\mathbf{2}}\right)$ & \% of Total Area \\
\hline Very low & $3,305,000$ & 8.14 & $2,835,500$ & 6.98 \\
Low & $3,258,000$ & 8.02 & $4,464,000$ & 10.99 \\
Medium & 242,000 & 0.60 & 203,000 & 0.50 \\
High & 85,500 & 0.21 & 214,500 & 0.53 \\
Very high & 104,000 & 0.26 & 160,500 & 0.40 \\
TOTAL & $6,994,500$ & 17.22 & $7,877,500$ & 19.40 \\
\hline
\end{tabular}

The physical risk was not included in this comparison, as there was no alternative input data available with a higher level of detail for buildings or roads than the default OpenStreetMap data.

\section{Discussion}

The generated flood hazard maps show the large impact of flooding on the study area. Even the 2-year flood affects 13.08 percent of the total catchment area. The extent of the floods with return periods of 10 and 50 years are only slightly larger than this 2-year flood extent. This can be attributed to the regions topography. As the plain of the river is low-lying and flat, this area will inundate completely whenever a flood occurs, independent from the return period of this flood. Therefore, it is most likely that a computed 1-year flood would have an extent only slightly smaller than the one of the 2-year flood. However, no flood map was generated for a return period of one year, as the $30 \times 30$ SRTM DEM was too coarse to see any difference from the 2-year flood map. When there are funds available for the acquisition of detailed data, the toolbox user should focus on acquiring a high-resolution DTM.

A detailed validation of the flood hazard maps for the study area is not feasible due to lack of adequate measurements. Nevertheless, expert judgement indicates that the simulated floods were realistic enough for the purposes of the risk mapping, as the same methodology showed adequate and validated results in Papua New Guinea [26].

Figures 8 and 9 present the resulting social, economic and physical vulnerability and risk maps for the catchment. These maps are an important visual tool for decision makers to comprehend the 
distribution of vulnerability and risk in the area. Both results were classified in five levels. The class values were determined to create an optimal visual result based on the average population density in the study area for social vulnerability and risk, and on the location-specific replacement values for economic and physical vulnerability and risk. In other case studies, the user can choose the number of vulnerability and risk classes, that will then be calculated by the toolbox based on the population density and replacement values of that specific location, in order to generate a clear visual result.

The social vulnerability and risk were based on WorldPop data as input data. As Worldpop distributes the population numbers using land use data, the population density is nowhere equal to zero. However, this study area is a predominantly rural region, with most inhabitants living concentrated in small villages. Although the total population number for the catchment is correct using WorldPop data, the distribution overestimates the population in the rural areas and underestimates it in the villages. This explains the large overestimation of the number of people living in the plain. Moreover, due to the even distribution of the inhabitants, there is a large error in the social risk map of the plain, as the area at risk using the default WorldPop data is 64 times larger than the area at risk using the detailed population data. When evaluating the number of people at risk, however, the WorldPop data underestimates this drastically, as only 939 inhabitants are situated in the area at risk, while the detailed data leads to 1798 people at risk. This is due to the fact that almost all inhabitants live in the villages, which are located in the flood zone. Therefore, 97.40 percent of all inhabitants of the plain are classified as at risk. The WorldPop data, on the other hand, distributes the number of people evenly across the plain, and as such, more people are situated outside the floodzone, as only 29.88 percent of the total population in the plain is at risk using the default methodology. The WorldPop shows thus clear shortcomings in this rural area. Moreover, WorldPop is not available for every country in the world. This is a major disadvantage of WorldPop as default data in the toolbox, as global coverage is an important condition for the input data.

The validation of the economic risk was done using more detailed farmland input data. This data replaced the GlobCover default data with a resolution of only $300 \mathrm{~m} \times 300 \mathrm{~m}$. For buildings and roads, OpenStreetMap was used as this is the most detailed information available for this study area. When comparing the results, the detailed crop data leads to a lower risk, specifically 2.18 percent less than the default data. As this is a rural area, the crop data has a significant effect on the result. However, as the damage cost of agricultural lands is substantially lower than the cost of roads and buildings, this effect is only visible within the lower risk levels. While the GlobCover data does lead to a small overestimation, mainly due to its low resolution and lack of detail, this overestimation remains limited and the result remains a valuable overview of the risk and its distribution within the area.

The default input data for physical vulnerability and risk is building and road information from OpenStreetMap. The building data shows the building footprints and the road data shows the axes of all roads. This data is the most detailed available and, therefore, no validation could be made with other input.

\section{Conclusions}

The developed methodology and toolbox allow experts in developing countries and data poor regions to perform reliable flood risk assessments and generate the necessary hazard, vulnerability and risk maps. The generic workflow is a robust and customizable algorithm that can be applied to any study area; it can be based on 'default data', which is freely available from different sources, but it can also be enriched with data surveyed within the study area. However, complete global coverage remains one of the most difficult conditions for the default input data. Although all data used is available in most parts of the world, it is impossible to ensure that the toolbox will provide results for every study area worldwide. The exact restrictions in geographic distribution are being mapped and listed and will be added to the toolbox manual.

The first case study for the catchment of the river Moustiques shows promising results. Despite the lack of historical hydro-meteorological data, the use of a physically-based distributed flood model 
using open remote sensing data gives a scientific base to flood mapping in this data-poor region. With no perspective on ever acquiring on-site hydrological data, the flood model should however be validated in the future using aerial photos of flood areas or local reporting on disasters when they become available. Also, the WorldPop data has proven to be inaccurate for rural areas. More test cases should be carried out in urban and semi-urban areas to determine the accuracy of WorldPop data in these regions. Furthermore, due to the lack of WorldPop data for some countries, another methodology to link population numbers based on census data and building locations from OpenStreetMap is developed and tested to replace the WorldPop data as input.

The economic risk map based on default data shows a good representation of the risk, although it depicts a small overestimation compared to the risk map based on detailed data. This is caused by the large presence of farmlands, that cover the lion part of the catchment. Furthermore, the resolution of GlobCover data is too coarse for a small study area as the catchment of the river Moustiques. Therefore, additional test cases will be chosen based on their land use distribution and their scale. As such, the impact and the accuracy of GlobCover data will be further examined.

In a next step, the toolbox shall be tested further on case studies in other countries, developed as well as developing, to validate the available replacement values, depth-damage functions and depth-mortality functions. Finally, additional natural hazards will be incorporated in the mapping methodology to develop a multi-hazard risk assessment tool, applicable worldwide that provides clear and practical risk maps. After this validation and testing phase, the toolbox will be made publicly and open source available.

Author Contributions: Conceptualization, H.G., I.R., G.D., P.D.M., D.S.C., E.M. and S.H.; methodology, H.G., I.R., G.D., D.S.C., E.M. and S.H.; software, H.G., S.H. and K.C.; validation, H.G.; formal analysis, H.G.; investigation, H.G.; resources, H.G., I.R., G.D. and S.H.; data curation, H.G., D.S.C., E.M. and S.H.; writing-original draft preparation, H.G.; writing - review and editing, H.G., I.R., D.S.C., E.M. and G.D.; visualization, H.G. and S.H.; supervision, H.G. and I.R.; project administration, H.G. and I.R.; funding acquisition, H.G.

Funding: The field work done for this research was partially funded by Research Foundation-Flanders (FWO) (travel grant: K225217N).

Acknowledgments: The authors would like to thank Join for Water, our Belgian partners as well as the local Haitian employees, for facilitating the field work and sharing their knowledge and data on the study area. Furthermore, we would like to thank Bruce Robinson and everyone at ODRINO for assisting us on the field and aiding in any way possible during our stay in Moustiques.

Conflicts of Interest: The authors declare no conflict of interest.

\section{References}

1. UNDRR. Gar Atlas: Unveiling Global Disaster Risk; United Nations Office for Disaster Risk Reduction (UNDRR): Geneva, Switzerland, 2017.

2. Zwenzner, H.; Voigt, S. Improved estimation of flood parameters by combining space based sar data with very high resolution digital elevation data. Hydrol. Earth Syst. Sci. 2009, 13, 567-576. [CrossRef]

3. UNDRR. Global Assessment Report on Disaster Risk Reduction; United Nations Office for Disaster Risk Reduction (UNDRR): Geneva, Switzerland, 2019.

4. Keating, A.; Mechler, R.; Mochizuki, J.; Kunreuther, H.; Bayer, J.; Hanger, S.; McCallum, I.; See, L.; Williges, K.; Hochrainer-Stigler, S. Operationalizing Resilience against Natural Disaster Risk: Opportunities, Barriers, and a Way forward; Zurich Flood Resilience Alliance: Zurich, Switzerland, 2014.

5. Deckers, P.; Kellens, W.; Reyns, J.; Vanneuville, W.; De Maeyer, P. A Gis for Flood Risk Management in Flanders; Geospatial Techniques in Urban Hazard and Disaster Analysis; Springer: Dordrecht, The Netherlands, 2009; pp. 51-69.

6. UNDRR. Unisdr Annual Report 2017, 2016-17 Biennium Work Programme Final Report; United Nations Office of Disaster Risk Reduction (UNDRR): Geneva, Switzerland, 2018.

7. Tate, E.; Munoz, C.; Suchan, J. Uncertainty and sensitivity analysis of the hazus-mh flood model. Nat. Hazards Rev. 2015, 16, 10. [CrossRef] 
8. Kok, M.; Huizinga, H.J.; Vrouwenvelder, A.C.W.M.; Barendregt, A. Standaardmethode 2004 - Schade En Slachtoffers Als Gevolg Van Overstromingen; RWS Dienst Weg- en Waterbouwkunde: Delft, The Netherlands, 2005; p. 60.

9. Apel, H.; Aronica, G.T.; Kreibich, H.; Thieken, A.H. Flood risk analyses-how detailed do we need to be? Nat. Hazards 2009, 49, 79-98. [CrossRef]

10. Glas, H.; Deruyter, G.; De Maeyer, P.; Mandal, A.; James-Williamson, S. Analyzing the sensitivity of a flood risk assessment model towards its input data. Nat. Hazards Earth Syst. Sci. 2016, 16, 2529-2542. [CrossRef]

11. Son, N.T.; Chen, C.F.; Chen, C.R. Flood assessment using multi-temporal remotely sensed data in Cambodia. Geocarto Int. 2019, 16. [CrossRef]

12. Kwak, Y.; Shrestha, B.B.; Yorozuya, A.; Sawano, H. Rapid damage assessment of rice crop after large-scale flood in the cambodian floodplain using temporal spatial data. IEEE J. Sel. Top. Appl. Earth Observ. Remote Sens. 2015, 8, 3700-3709. [CrossRef]

13. Kumar, R.; Acharya, P. Flood hazard and risk assessment of 2014 floods in kashmir valley: A space-based multisensor approach. Nat. Hazards 2016, 84, 437-464. [CrossRef]

14. Brandimarte, L.; Brath, A.; Castellarin, A.; Di Baldassarre, G. Isla hispaniola: A trans-boundary flood risk mitigation plan. Phys. Chem. Earth 2009, 34, 209-218. [CrossRef]

15. Heimhuber, V.; Hannemann, J.C.; Rieger, W. Flood risk management in remote and impoverished areas-a case study of onaville, haiti. Water 2015, 7, 3832-3860. [CrossRef]

16. UNDRR. Unisdr Terminology on Disaster Risk Reduction; United Nations Office for Disaster Risk Reduction (UNDRR): Geneva, Switzerland, 2009.

17. De Roo, A.; Offermans, R.; Cremers, N. Lisem: A single-event, physically based hydrological and soil erosion model for drainage basins. Ii: Sensitivity analysis, validation and application. Hydrol. Process. 1996, 10, 1119-1126. [CrossRef]

18. De Roo, A.; Wesseling, C.; Cremers, N.; Offermans, R.; Ritsema, C.; Van Oostindie, K. Lisem: A new physically-based hydrological and soil erosion model in a gis-environment, theory and implementation. IAHS Publ. Ser. Proc. Rep. Intern. Assoc. Hydrol. Sci. 1994, 224, 439-448.

19. Aston, A. Rainfall interception by eight small trees. J. Hydrol. 1979, 42, 383-396. [CrossRef]

20. von Hoyningen-Huene, J. Die Interzeption Des Niederschlags in Landwirtschaftlichen Pflanzenbeständen; Arbeitsbericht Deutscher Verband für Wasserwirtschaft und Kulturbau, DVWK: Hennef, Germany, 1981.

21. Kamphorst, E.; Jetten, V.; Guérif, J.; Iversen, B.; Douglas, J.; Paz, A. Predicting depressional storage from soil surface roughness. Soil Sci. Soc. Am. J. 2000, 64, 1749-1758. [CrossRef]

22. Green, W.H.; Ampt, G. Studies on soil phyics. J. Agric. Sci. 1911, 4, 1-24. [CrossRef]

23. Farrell, D.; Larson, W. Modeling the pore structure of porous media. Water Resour. Res. 1972, 8, 699-706. [CrossRef]

24. Delestre, O.; Darboux, F.; James, F.; Lucas, C.; Laguerre, C.; Cordier, S. Fullswof: Full Shallow-Water Equations for Overland Flow. J. Open Source Softw. 2017, 2, 448. [CrossRef]

25. Jetten, V. Openlisem Multi-Hazard Land Surface Process Model, Documentation and User Manual; University of Twente: Enschede, The Netherlands, 2018.

26. Karssenberg, D.; Schmitz, O.; Salamon, P.; de Jong, K.; Bierkens, M.F. A software framework for construction of process-based stochastic spatio-temporal models and data assimilation. Environ. Model. Softw. 2010, 25, 489-502. [CrossRef]

27. Berlamont, J. The Influence of Rainfall and Model Simplification on Combined Sewer System Design; Katholieke Universiteit Leuven: Leuven, Belgium, 1999.

28. World Bank. Road Costs Knowledge System (Rocks) Version 2.3 User's Guide; World Bank: Washington, DC, USA, 2006.

29. Turner \& Townsend. International Construction Market Survey 2018; Turner \& Townsend: Leeds, UK, 2018.

30. Compass International Inc. Global Construction Costs Yearbook 18th Edition; Compass International Inc.: Manila, Philippines, 2018.

31. Dutta, D.; Herath, S.; Musiake, K. A mathematical model for flood loss estimation. J. Hydrol. 2003, $277,24-49$. [CrossRef]

32. Vanneuville, W.; De Maeyer, P.; Maeghe, K.; Mostaert, F. Model the effects of a flood in the dender catchment based on a risk methodology. Bull. Soc. Cartogr. 2003, 37, 59-64. 
33. Vrisou van Eck, N.; Kok, M.; Vrouwenvelder, A. Standaardmethode Schade en Slachtoffers als Gevolg van Overstromingen, Deel 2: Achtergronden; HKV Lijn in Water, TNO, Dienst Weg en Waterbouw: Delft, The Netherlands, 1999.

34. FAOSTAT. Crops. Available online: http://www.fao.org/faostat/en/\#data/QC (accessed on 8 October 2018).

35. Rossilon, F. Face à la détresse humaine et environnementale, gestion intégrée de l'eau et ecosanté, leviers de développement pour une haïti nouvelle. In L'eau dans les Pays en Développement - Retour D'expériences de Gestion Intégrée et Participative Avec les Auteurs Locaux; Editions Johanet: Paris, France, 2016; pp. 313-366.

36. PROTOS. Évaluation Transversale 2010 - Mise En CEuvre de la Stratégie Gire et Intégration de la Problématique Changement Climatique - Etude de cas - Haïti; PROTOS: Ghent, Belgium, 2011.

37. Government of Haiti. Analysis of Multiple Natural Hazards in Haiti (Nathat); Government of Haiti: Haiti, 2010.

38. Glas, H.; Deruyter, G.; De Maeyer, P. Flood risk assessment in data sparse regions: The use of questionnaires to collect historic flood data-a case study for the river moustiques in haiti. Int. Multidiscip. Geoconference SGEM 2018 2018, 18, 377-384.

(C) 2019 by the authors. Licensee MDPI, Basel, Switzerland. This article is an open access article distributed under the terms and conditions of the Creative Commons Attribution (CC BY) license (http://creativecommons.org/licenses/by/4.0/). 